\title{
XPA Gene
}

National Cancer Institute

\section{Source}

National Cancer Institute. XPA Gene. NCI Thesaurus. Code C20361.

This gene facilitates DNA binding in repair processes and is associated with the disease xeroderma pigmentosum complementation group $\mathrm{A}$. 